\title{
Altered Autonomic Functions in Exam Stress: Cardiovascular-Pulmonary Interactions
}

\section{Sınav Stresinde Değișen Otonomik Fonksiyonlar: Kardiyovasküler-Pulmoner Etkileşimler}

\author{
Seyhan TAŞKIN 1 - \\ ${ }^{1}$ Harran University, Medical Faculty, Department of Physiology, Sanliurfa, Turkey
}

\section{Abstract}

Background: Medical training involves a long and exhaustive curriculum in which students are frequently evaluated by examinations. Pre-examination stress is a common condition faced by students prior to exams and is one of the most widely experienced problems for medical students. The aim of the study was to assess the effects of exam stress on autonomic nervous system functions of students through cardiovascular parameters and respiratory tests.

Materials and Methods: The study group consisted of 29 second-year medical students. This cross-sectional study was carried out from February to March 2020 at Harran University, Turkey. The parameters used were oxygen saturation, pulse rate (PR), systolic (SBP) and diastolic blood pressure (DBP), and pulmonary function tests. Data were collected four times during an exam period (10 days, 7 days, and 1 hour before the exam and 1 hour after the exam).

Results: There was a statistically significant difference between the measurements of PR, SBP, and DBP at different times ( $p<0.001 ; p=0.001 ; p=0.003$, respectively). When the average values of the measurements of Forced vital capacity (FVC), forced expiratory volume in 1 second $\left(\mathrm{FEV}_{1}\right)$, peak expiratory flow (PEF), and vital capacity (VC) at different times were compared, it was found that there was a statistically significant difference between the groups $(p<0.001 ; p=0.006 ; p<0.001 ; p<0.001$, respectively). As a result of the sympathetic nervous system induction, hemodynamic and respiratory tests increased gradually until the examination. The results of correlation analysis showed a negative relationship between PR, and FVC, FEV 1 , VC.

Conclusions: It is evident that medical students undergo stress during their pre-exam period. It is thought that constant exposure to stress can disrupt the homeostatic balance in the long term and may be risk factor for cardiovascular and respiratory diseases.

Key Words: Stress; Hemodynamics; Pulmonary function test; Medical students; Exam

Öz.

Amaç: Tıp eğitimi, öğrencilerin sık sık sınavlarla değerlendirildiği uzun ve kapsamlı bir müfredata sahiptir. Sınav öncesi stres, öğrencilerin sınavlardan önce karşılaştıkları yaygın bir durumdur ve özellikle tıp öğrencilerinin en müzdarip olduğu sorunlardan biridir. Çalışmanın amacı, sınav stresinin öğrencilerin otonom sinir sistemi aktivitelerine etkisini kardiyovasküler parametreler ve solunum testleri ile değerlendirmektir.

Materyal ve Metod: Çalışmaya ikinci sınıf tıp öğrencilerinden 29 kişi dahil edildi. Bu kesitsel çalışma, Şubat-Mart 2020 tarihleri arasında Harran Üniversitesi, Türkiye'de gerçekleştirildi. Kullanılan parametreler; oksijen satürasyonu, nabız hızı (PR), sistolik (SBP) ve diyastolik kan basıncı (DBP) ve solunum fonksiyon testleri idi. Veriler öğrencilerin sınav döneminde dört farklı zamanda toplandı. (Sınavdan 10 gün, 7 gün ve 1 saat önce ve sınavdan 1 saat sonra).

Bulgular: Sınav döneminde farklı zamanlarda ölçülen PR, SBP ve DBP arasında istatistiksel olarak anlamlı fark vardır (sırasıyla $p<0.001 ; p=0.001 ; p=0.003)$. Zorlu vital kapasite $(F V C)$, birinci saniyedeki zorlu ekspiratuar hacim $\left(F E V_{1}\right)$, pik ekspiratuar akım (PEF) ve vital kapasitenin (VC) ortalama değerleri karşılaştıııldığında, gruplar arasında istatistiksel olarak anlamlı bir fark tespit edilmiștir (sırasıyla $p<0.001 ; p=0.006 ; p<0.001 ; p<0.001$ ). Sempatik sinir sistemi indüksiyonu sonucunda sınav anına kadar hemodinamik parametreler ve solunum testleri kademeli olarak arttı. Yapılan korelasyon analizinin sonuçları PR ile $\mathrm{FVC}, \mathrm{FEV}_{1}, \mathrm{VC}$ arasında negatif bir ilişki olduğunu gösterdi. Sonuç: Tıp öğrencilerinin sınav öncesi dönemde stres altında oldukları açıktır. Sürekli olarak strese maruz kalmanın uzun vadede homeostatik dengeyi bozabileceği, kardiyovasküler ve solunum yolu hastalıkları için bir risk faktörü olabileceği düşünülmektedir.

Anahtar kelimeler: Stres; Hemodinamik; Solunum fonksiyon testi; Tıp öğrencisi; Sınav
Sorumlu Yazar / Corresponding Author

Seyhan TAŞKIN

Harran University Medical Faculty Department of Physiology, Osmanbey Campus, Haliliye, 63300, Sanliurfa/Turkey

E-mail: syhntskn@gmail.com

Geliş tarihi / Received:

16.03.2021

Kabul tarihi / Accepted: 22.04.2021

DOI: 10.35440/hutfd.898077 


\section{Introduction}

Stress can be defined as the body's reaction to a change that requires physical, mental, and emotional harmony or reaction (1). While mild stress levels have beneficial effects on cognitive performance, constantly high levels of stress exposure can lead to anxiety and depression (2). The main components of the stress system are corticotropin-releasing hormone ( $\mathrm{CRH}$ ) and locus coeruleus-norepinephrine-autonomic systems, as well as their environmental effectors (3). As a result of the activation of the stress system, physiological and behavioral changes are seen in the body. The neuroendocrine response, which covers a range of coordinated responses, is provided by the autonomic nervous system and Hypothalamus-Pituitary Gland-Adrenal (HPA) axis. The basic endocrine response, which occurs in the state of stress, begins with the release of $\mathrm{CRH}$ from the hypothalamus. $\mathrm{CRH}$ causes the release of adrenocorticotropic hormone (ACTH) from the anterior pituitary, and ACTH affects the adrenal cortex, causing glucocorticoid release. In short, stressors trigger the activation of the autonomic nervous system and HPA axis through mechanisms involving the hypothalamus and brainstem. Thus, the HPA axis activates the sympathetic system, leading to changes in pulse rate, blood pressure, respiratory rate and depth, reaction time, and body temperature $(4,5)$.

Physiological control of changes that vital importance in respiratory and pulse rate is carried out by complex factors such as baroreflex, chemoreflex and hormones (6). Respiratory sinus arrhythmia (RSA) is one of the important physiological interactions between breathing and circulation. The heart rate increases during inspiration and decreases during expiration. RSA increases respiratory gas exchange by synchronizing the heartbeat and breathing rhythm. Therefore, the distribution of heartbeats within each respiratory cycle can critically affect the ventilation and perfusion (7). Stress-related activity of RSA changes depending on the type of stress factors. It was found that RSA magnitude decreased in cognitive activities where sympathetic discharges (high cognitive control) were effective, and RSA increased in cognitive activities where emotional stimuli (low cognitive control) were effective $(8,9)$.

Medical education involves long-term training to enable graduates to become professional medical personnel. During training, the curriculum is broad, and students are assessed through regular examinations (10). Students work for long hours to succeed, often beyond their stress-causing mental thresholds and physical strengths. For this reason, it is accepted that medical students are under stress, especially before exams (11).

Stress in the pre-exam period is one of the main problems that medical students worldwide experience. In studies where the physiological and psychological effects of exams, as acute stressors, are investigated, medical faculty students are preferred as subjects (5). The purpose of this study is to evaluate the effects of medical students' stress on the autonomic nervous system functions during the academic exam period (before and after exams) through cardiovascular parameters and respiratory tests.

\section{Materials and Methods}

\section{Experimental Design and Participants}

The study group consisted of 29 second-year medical students-11 males and 18 females. This cross-sectional study was carried out from February to March 2020 at Harran University, Şanlıurfa, Turkey. All subjects were within the age group of 18 to 21 years old. Participants with a history of neurological or psychiatric disorders, taking medicines that affect emotional status and endocrinological profile, or addiction to tobacco or alcohol were excluded from the study (11). This study was approved by the Harran University Clinical Research Ethics Committee (No: HRU/20.02.21). Informed and written consent was also obtained from the volunteers.

At the beginning of the study, the height and weight of the participants were measured and their body mass indexes (BMI) were calculated. The physiological parameters analyzed in the study-heart rate, systolic, and diastolic blood pressure, oxygen saturation, and pulmonary function test-were measured at four different times (Each different measurement time was defined as a group). The first measurement was taken 10 days before the exam, the second was taken 7 days before the exam, the third was taken 1 hour before the exam, and the final measurement was taken 1 hour after the exam. The measurements were taken in a quiet room to alleviate any emotional or psychological stresses experienced by the students. Before the measurements were taken, participants rested in a sitting position for 5 minutes.

\section{Cardiovascular Parameters}

A digital automatic sphygmomanometer (Braun, Frankfurt, Germany) was used to record the systolic blood pressure (SBP, $\mathrm{mmHg}$ ), diastolic blood pressure (DBP, $\mathrm{mmHg}$ ), and pulse rate ( $P R$, beats per minute) of the participants. The blood pressure and pulse rate of the right arm were assessed in a sitting position. The formulas used to calculate mean arterial pressure $(\mathrm{MAP}, \mathrm{mmHg})$ and pulse pressure $(\mathrm{PP}, \mathrm{mmHg})$ were as follows: $\mathrm{MAP}=\mathrm{DBP}+1 / 3(\mathrm{SBP}-$ $\mathrm{DBP}$ ) and $\mathrm{PP}=\mathrm{SBP}-\mathrm{DBP}$. Rate pressure product (RPP), defined as the myocardial oxygen uptake index, helped the evaluation of the myocardial stress of the participants (12). RPP was calculated using the following formula $(13,14): R P P=(P R \times S B P) / 1000$. Oxygen saturation $\left(\mathrm{SpO}_{2} \%\right)$ was monitored noninvasively for 1 minute from the index finger of the participants with a pulse oximeter (Nonin Onyx II, Minnesota, USA).

\section{Pulmonary Function Test}

Pulmonary function test measurements were carried out using a portable spirometer device (MiniSpir, Roma, 
Italy). The best of three maneuvers compatible with each other was chosen. Forced vital capacity (FVC), forced expiratory volume in 1 second $\left(F V_{1}\right)$, the ratio of forced expiratory volume in 1 second to forced vital capacity (FEV $1 / F V C)$, peak expiratory flow (PEF), forced expiratory flow $25-75 \%$ (FEF25-75), and vital capacity (VC) values were recorded. The maximum voluntary ventilation (MVV) values were recorded computationally.

\section{Statistical Analysis}

Statistical analysis was performed using the SPSS 20.0 package program (SPSS Inc., Chicago, IL, USA). The minimum necessary sample size ( $\mathrm{n}: 28)$ was determined by power analysis (with an effect size of 0.55 , an $\alpha$ error probability of 0.05 and an actual power of 0.80 ) using GPower program (Version 3.1.9.4, Germany). The normality of continuous variables was tested by the Kolmogorov-Smirnov test. All data were presented as the mean \pm standard deviation. A repeated measures ANOVA was used for the statistical analysis of the parameters measured at four different times. The differences between the two groups were determined by Post-Hoc LSD test. Correlation between the hemodynamic and respiratory parameters was analyzed with Pearson correlation analysis. A value of $p<0.05$ was considered to indicate a statistically significant difference.

\section{Results}

A total of 29 subjects participated in this study, of which 11 were male and 18 were female. The mean age was $20.17 \pm 0.17$ years, mean height was $1.69 \pm 0.02 \mathrm{~m}$, and mean BMI was $22.16 \pm 0.51 \mathrm{~kg} / \mathrm{m}^{2}$.

The data for the hemodynamic parameters, measured at four different times (10 days, 7 days, and 1 hour before the exam and 1 hour after the exam), were shown in Table 1 . There was a statistically significant difference between the measurements of PR, SBP, and DBP at different times ( $p<0.001 ; p=0.001 ; p=0.003$, respectively). According to the partial eta-squared analysis, $82.9 \%$ of the change in PR, $44.4 \%$ of the change in SBP, and $40.6 \%$ of the change in DBP explain the increasing stress. When PR, $\mathrm{SBP}$, and DBP levels measured at different time periods were examined, it was found that while it increased linearly up to 1 hour before the exam, it decreased after 1 hour (Fig. 1). While there was a statistically significant difference between the measurements of MAP and RPP values at the four measurement points $(p<0.001 ; p<0.001$; respectively), there was no statistically significant difference in PP value between the groups $(p=0.628)$. According to the partial eta-squared analysis, exam stress was responsible for $58.52 \%$ of the change in MAP and $80.4 \%$ of the change in RPP. Peak values were found in the measurement of the cardiovascular parameters, which was accepted as the highest stress period, 1 hour before the exam. $\mathrm{SpO}_{2}$ was found to be at the same level, on ave- rage, at all times (98\%), and there was no statistically significant difference between the groups $(p=0.513)$.

The data for the participants' pulmonary function test results were summarized in Table 2. Overall, a gradual increase was found in all parameters (excluding FEV $1 / F V C$ ) until the measurements taken on the day of the exam. In the measurement taken after the exam, the average values of these variables decreased compared to those taken 1 hour before the exam. When the average values of the measurements of FVC, FEV $1, P E F, V C$, and MVV at different times were compared, it was found that there was a statistically significant difference between the groups $(p<0.001 ; p=0.006 ; p<0.001 ; p<0.001 ; p=0.006$, respectively). According to the partial eta-squared analysis, exam stress was responsible for $59.1 \%$ of the change in FVC, $37.8 \%$ of the change in $\mathrm{FEV}_{1}, 67.5 \%$ of the change in PEF, $63.8 \%$ of the change in VC and $37.8 \%$ of the change in MVV. When FVC, FEV 1 , and VC levels measured at different time periods were examined, it was found that while it increased linearly up to 1 hour before the exam, it decreased after 1 hour (Fig. 2). It is clear that the PR, and FVC, $\mathrm{FEV}_{1}$ and $\mathrm{VC}$ values increased with the effect of exam stress. The results of correlation analysis showed a negative relationship between $\mathrm{PR}$, and FVC, FEV 1 , VC (PR-FVC; $r:-0.452, p<0.001 ; \mathrm{PR}-\mathrm{FEV}_{1} ; r:-0.388, p<0.001 ; \mathrm{PR}-\mathrm{VC} ; r$ :$0.414, p<0.001$ ) (Fig. 3).

It was found that people with high PR had a lower FVC, FEV 1 , and VC, while people with low PR had a greater FVC, $\mathrm{FEV}_{1}$, and VC.

\section{Discussion}

Stress is a phenomenon experienced during a long and strenuous medical education. Long working hours, frequent exams, a competitive environment, and a lack of social activities are some of the causes of stress. The high prevalence of stress among medical students is a source of concern, as it may cause psychological and behavioral changes in students and affect learning and their professional life after graduation $(15,16)$. Students are under more stress than the moment of exam application as they prepare for an exam. This offers an important time for observation to examine the stress experienced and its effects (17). This study aimed to investigate the effects of stress on the autonomic nervous system activities before and after an exam.

Stress directly or indirectly affects the brain stem, and the levels of catecholamines are increased through sympathetic nervous system stimulation. The main effect on the heart systems, as a result of activation of $\alpha 1, \beta 1$, and $\beta 2$ receptors, is an increase in heart rate and blood pressure (18). In the present study, the significant increase in PR, $\mathrm{SBP}$, and DBP values of the students one hour before the exam, compared to a week before the exam, can be explained as the sympathoadrenal response to stress. 
Table 1. Cardiovascular response to exam stress at different time periods.

\begin{tabular}{|c|c|c|c|c|c|c|c|c|c|}
\hline Variable & 10 days before & 7 days before & 1 hour before & 1 hour after & $p$-value/partial eta-squared & \multicolumn{4}{|c|}{ Significance } \\
\hline PR (bpm) & $84.93 \pm 13.71$ & $84.89 \pm 13.78$ & $104.79 \pm 13.78$ & $88.58 \pm 13.98$ & $<0.001 / 0.829$ & + & $\S$ & ๆ & \\
\hline $\mathrm{SPO}_{2}(\%)$ & $98.51 \pm 0.68$ & $98.24 \pm 0.68$ & $98.37 \pm 0.56$ & $98.20 \pm 0.86$ & $0.513 / 0.083$ & & & & \\
\hline SBP $(\mathrm{mmHg})$ & $124.65 \pm 13.82$ & $120.31 \pm 13.54$ & $128.58 \pm 11.99$ & $124.31 \pm 11.62$ & $0.001 / 0.444$ & $\S$ & & & \\
\hline DBP $(\mathrm{mmHg})$ & $74.06 \pm 10.20$ & $71.03 \pm 9.85$ & $79.48 \pm 11.96$ & $77.37 \pm 12.32$ & $0.003 / 0.406$ & $\dagger$ & $\S$ & II & \\
\hline PP (mmHg) & $50.58 \pm 10.07$ & $49.29 \pm 11.81$ & $49.10 \pm 11.02$ & $46.93 \pm 7.63$ & $0.628 / 0.064$ & & & & \\
\hline MAP (mmHg) & $90.93 \pm 10.51$ & $87.45 \pm 9.74$ & $95.85 \pm 10.79$ & $93.02 \pm 11.55$ & $<0.001 / 0.585$ & $*$ & $\dagger$ & $\S$ & II \\
\hline RPP & $10.61 \pm 2.25$ & $10.22 \pm 2.06$ & $13.45 \pm 2.01$ & $10.99 \pm 1.97$ & $<0.001 / 0.804$ & + & $\S$ & १ & \\
\hline
\end{tabular}

The data represent as mean \pm SD. p-value significance from repeated measures (Wilks' Lambda) analysis: The significantly different $(p<0.05)$ groups are flagged with $*, t, \delta, / /$ and $\eta . *, 10$ days before vs. 7 days before; $t, 10$ days before vs. 1 hour before; $\S, 7$ days before vs. 1 hour before; / , 7 days before vs. 1 hour after; 9 , 1 hour before vs. 1 hour after. PR: Pulse rate, $\mathrm{SpO}_{2}$ : Oxygen saturation, SBP: Systolic blood pressure, DBP: Diastolic blood pressure, PP: Pulse pressure, MAP: Mean arterial pressure, RPP: Rate pressure product.

Table 2. Pulmonary function tests measured 10 days, 7 days, and 1 hour before the exam and 1 hour after the exam.

\begin{tabular}{|c|c|c|c|c|c|c|c|c|c|c|}
\hline Variable & 10 days before & 7 days before & 1 hour before & 1 hour after & $p$-value/partial eta-squared & & ifi & inc & & \\
\hline FVC & $4.04 \pm 0.98$ & $4.20 \pm 0.99$ & $4.34 \pm 1.03$ & $4.22 \pm 0.99$ & $<0.001 / 0.591$ & * & + & $\ddagger$ & $\S$ & ๆ \\
\hline $\mathrm{FEV}_{1}$ & $3.54 \pm 0.83$ & $3.63 \pm 0.82$ & $3.74 \pm 0.84$ & $3.69 \pm 0.80$ & $0.006 / 0.378$ & $\dagger$ & $\ddagger$ & $\S$ & & \\
\hline $\mathrm{FEV}_{1} / \mathrm{FVC}$ & $88.31 \pm 8.89$ & $86.74 \pm 5.89$ & $86.64 \pm 5.83$ & $87.89 \pm 5.25$ & $0.285 / 0.133$ & & & & & \\
\hline PEF & $5.40 \pm 1.44$ & $6.39 \pm 1.92$ & $7.08 \pm 1.94$ & $7.03 \pm 2.05$ & $<0.001 / 0.675$ & $*$ & $\dagger$ & $\ddagger$ & $\S$ & | \\
\hline FEF25-75 & $4.14 \pm 1.08$ & $4.06 \pm 0.99$ & $4.19 \pm 0.91$ & $4.28 \pm 0.90$ & $0.252 / 0.143$ & & & & & \\
\hline VC & $3.83 \pm 0.76$ & $4.10 \pm 0.90$ & $4.23 \pm 0.94$ & $4.18 \pm 0.94$ & $<0.001 / 0.638$ & $*$ & $\dagger$ & $\ddagger$ & $\S$ & \\
\hline MVV & $124.20 \pm 29.09$ & $127.05 \pm 28.99$ & $130.96 \pm 29.57$ & $129.37 \pm 28.34$ & $0.006 / 0.378$ & $\dagger$ & $\ddagger$ & $\S$ & & \\
\hline
\end{tabular}

The data represent as mean $\pm S D$. p-value significance from repeated measures (Wilks' Lambda) analysis. The significantly different $(p<0.05)$ groups are flagged with $*, t, \neq, \xi, I /$, and $9 . *, 10$ days before vs. 7 days before; $t, 10$ days before vs. 1 hour before; $¥, 10$ days before vs. 1 hour after; $\delta, 7$ days before vs. 1 hour before; /I, 7 days before vs. 1 hour after; 9, 1 hour before vs. 1 hour after. FVC: Forced vital capacity, FEV 1 : Forced expiratory volume in 1 second, FEV 1 /FVC: The ratio of forced expiratory volume in 1 second to forced vital capacity, PEF: Peak expiratory flow, FEF2575: Forced expiratory flow 25-75\%, VC: Vital capacity, MVV: Maximum voluntary ventilation.

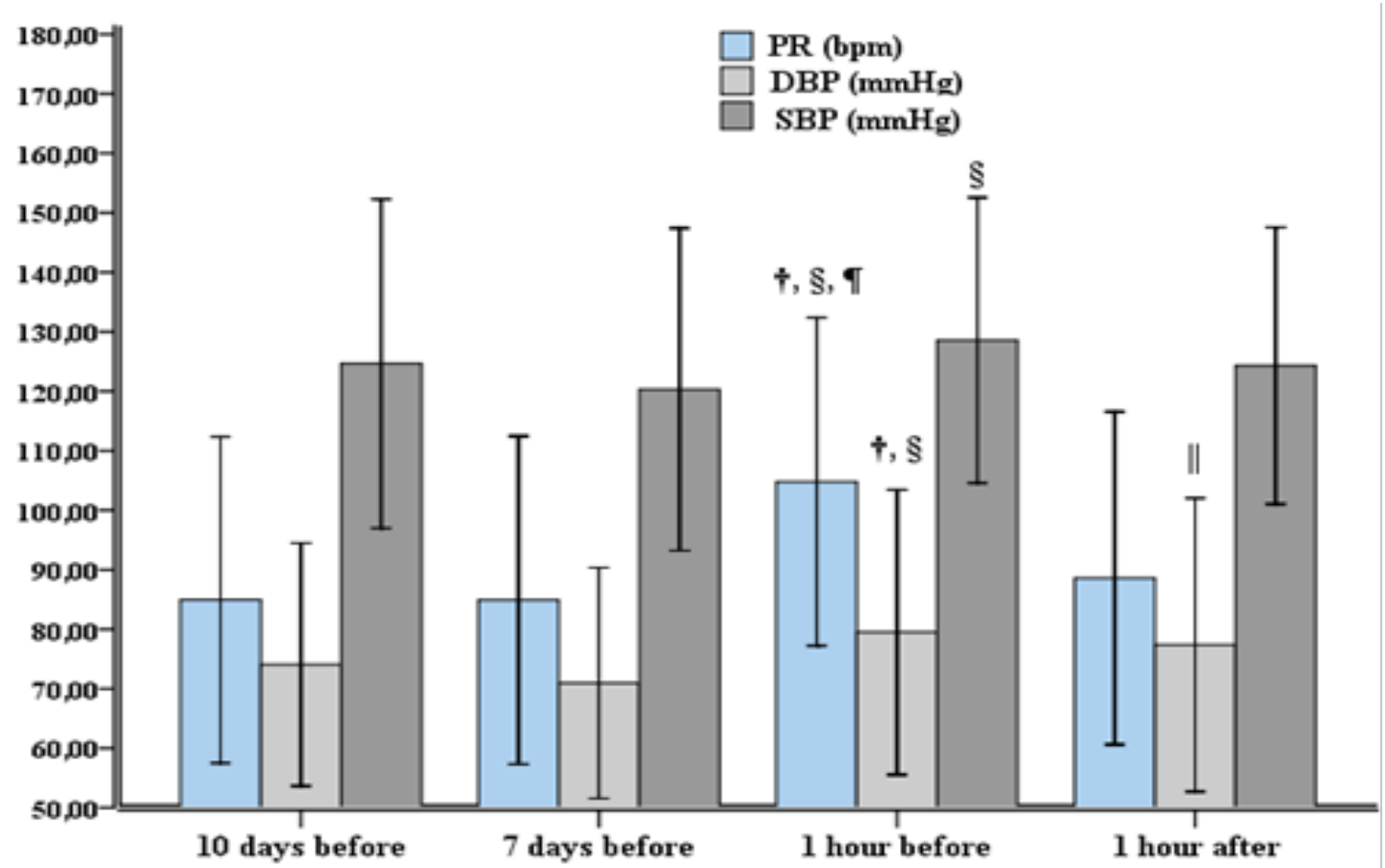

Figure 1. Comparison of hemodynamic parameters before and after the exam period

Hemodynamic parameters measured 10 days, 7 days, and 1 hour before the exam and 1 hour after the exam. PR: Pulse rate, SBP: Systolic blood pressure, DBP: Diastolic blood pressure. The significantly different $(p<0.05)$ groups are flagged with $+, \xi, \mid 1$, and $\eta .+, 10$ days before vs. 1 hour before; §, 7 days before vs. 1 hour before; I, 7 days before vs. 1 hour after; 9,1 hour before vs. 1 hour after. 


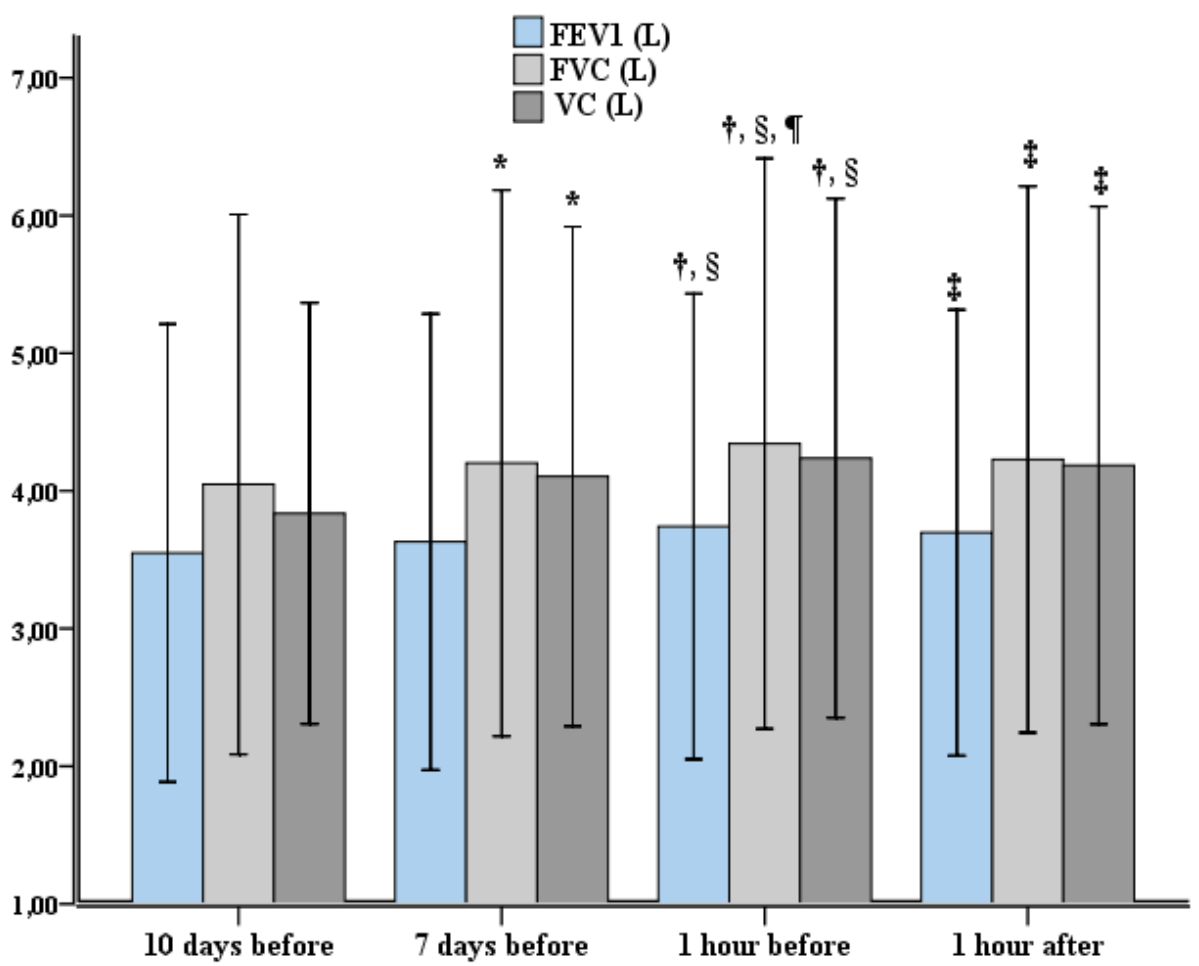

Figure 2. Comparison of respiratory parameters before and after the exam period

Respiratory tests measured 10 days, 7 days, and 1 hour before the exam and 1 hour after the exam. FVC: Forced vital capacity, FEV 1 : Forced expiratory volume in 1 second, VC: Vital capacity. The significantly different $(p<0.05)$ groups are flagged with *, $+\neq, \xi$, and $q . *, 10$ days before vs. 7 days before; $t, 10$ days before vs. 1 hour before; $\neq, 10$ days before vs. 1 hour after; $\S, 7$ days before vs. 1 hour before; 9,1 hour before vs. 1 hour after.

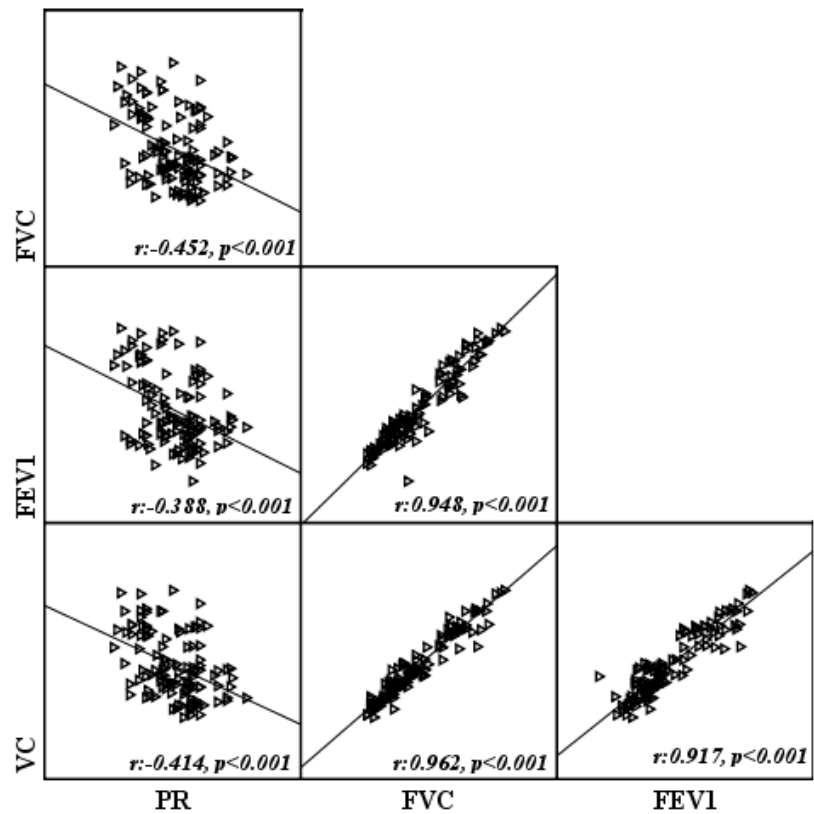

Figure 3. Correlation analysis between $\mathrm{PR}$, and FVC, FEV $1, \mathrm{VC}$

FVC: Forced vital capacity, FEV 1 : Forced expiratory volume in 1 second, VC: Vital capacity,

PR: Pulse rate 
The autonomic nervous system plays a vital role in the regulation of MAP through the baroreceptor reflex (19). As the exam approached, a significant increase in MAP value was detected linearly with increasing stress. The decrease observed in the mean PR, SBP, DBP, and MAP values after the exam, compared to the pre-exam values, can be explained by the decrease in cardiac output and peripheral arteriolar resistance as a result of decreased sympathetic discharges after the exam (19). It has been reported that mental arithmetic stress, physical stress (13), and examperiod stress (12) cause a significant increase in RPP. In our study, RPP was found to increase significantly with the effect of exam stress, reaching a peak value 1 hour before the exam. It is thought that a similar increase in PR, SBP and RPP may facilitate coronary perfusion, allowing the effect of acute mental stress to be tolerated without causing any cardiovascular damage (13).

Oxygen saturation measurement in peripheral blood is a commonly used noninvasive practice to assess pulmonary and cardiovascular integrity (20). In our study, the $\mathrm{SpO}_{2}$ value was found to be $98 \%$ at all measurement points, and exam stress did not cause hypoxemia. This situation is thought to be balanced with hemodynamic and respiratory changes in response to stress.

Autonomic nerves regulate airway functions through their effects on airway smooth muscle, bronchial vessels, and mucous glands (21). In stress studies, an increase in sympathetic stimulation due to stress induction is generally confirmed by an increase in heart rate. However, there is no consistent relationship between studies on average lung function changes. Contrary to studies reporting that there is a decrease in lung function in the presence of strong sympathetic induction (22) and a positive correlation between sympathetic excitation and respiratory resistance (20), there is a study reporting the presence of a positive correlation between post-stress epinephrine levels and PEF (23). In our study, it was determined that exam stress caused an increase in lung function. It was found that spirometry tests, such as FVC, FEV 1, PEF, $M V V$, and VC, done on the participants gradually increased until the exam and reached the highest level in the last measurement before the exam. This may be caused by bronchodilation through beta adrenergic receptors. Many stress factors also cause an increase in ventilation in humans. As a result of changes in breathing depth and frequency, minute ventilation is increased (24). In this study, the fact that the test stress caused a statistically significant change in MVV and VC can be interpreted as a sign of an increase in ventilation capacity. The absence of a relationship between groups at the $\mathrm{FEV}_{1} / \mathrm{FVC}$ ratio may be due to the fact that the subjects in our study did not have any respiratory problems.

Exam stress affects the hemodynamic parameters $(25,26)$ and respiratory functions of the participants. Medical students with high PR have a lower FVC, FEV 1 , and VC, and conversely, medical students with low PR have a higher
FVC, $F_{1}$, and $V C$. The presence of a negative correlation between $P R$ and $F E V_{1}, F V C$, and VC indicates that physiological compensation occurs through the dynamic balance between the respiratory cycle and PR. It is thought that RSA, baroreflex, chemoreflex, and hormones contribute to this physiological compensation mechanism. Cognitive task that require high and low cognitive control have been shown to affect RSA activity differently $(8,27,28)$. High RSA magnitude is associated with lower respiratory rate and respiratory activities, which are characterized by increased tidal volume (8). Although the type of cognitive function (arithmetic or emotional) affects RSA activity, the person's adaptation to stress and its different intensity from cognitive task may be determinant of RSA activity.

\section{Limitations}

The small number of participants and lack of biochemical parameters that confirm the stress status are limitations of this study.

\section{CONCLUSION}

It is a general conclusion proved that exams were one of the strongest stress factors for medical students. This study found that exam stress caused an increase in sympathetic activity, which led to a significant increase in pulse, blood pressure, and lung respiratory functions. The increase in sympathetic stimulation resulting from stress induction, as well as the continuous increase in hemodynamic activity and its inability to compensate in the long term, may be a risk factor for cardiovascular diseases.

\section{Acknowledgements \\ The author would like to thank Assoc. Prof. Hakim ÇELIK and Lec- turer Dr. Abdullah TAŞKIN for their suggestions and comments on the manuscript. \\ Ethical Approval: This study was approved by the Harran Uni- versity Clinical Research Ethics Committee (Date 12/02/2020 No: HRU/20.02.21). Informed and written consent was also ob- tained from the volunteers.}

\section{Author Contributions:}

Concept: S.T.

Literature Review: S.T.

Design : S.T.

Data acquisition: S.T.

Analysis and interpretation S.T.

Writing manuscript: S.T.

Critical revision of manuscript: S.T.

Conflict of Interest: Author declared no conflict of interest. Financial Disclosure: Author declared no financial support.

\section{References}

1. Sharma B, Wavare R, Deshpande A, Nigam R, Chandorkar R. A study of academic stress and its effect on vital parameters in final year medical students at SAIMS Medical College, Indore, Madhya Pradesh. Biomed Res. 2011; 22(3):361-365.

2. Singh R, Goyal M, Tiwari S, Ghildiyal A, Nattu SM, Das S. Effect of examination stress on mood, performance and cortisol levels in medical students. Indian J Physiol Pharmacol. 2012; 56(1):4855. 
3. Tsigos C, Chrousos GP. Hypothalamic-pituitary-adrenal axis, neuroendocrine factors and stress. J Psychosom Res. 2002; 53:865-871.

4. Bali A, Jaggi AS. Clinical experimental stress studies: Methods and assessment. Rev Neurosci. 2015; 26(5):555-579.

5. Shah SJ, Patel HM. Effect of Examination Stress on Parameters of Autonomic Functions in Medical Students. IJSR. 2014; 3(7):273-276.

6. Piskorski J, Guzik P. Asymmetric properties of long-term and total heart rate variability. Med Biol Eng Comput. 2011; 49:1289-1297.

7. Yasuma F, Hayano J. Respiratory Sinus Arrhythmia: Why Does the Heartbeat Synchronize with Respiratory Rhythm? Chest. 2004; 125(2):683-690.

8. Overbeek TJM, Boxtel AV, Westerink JHDM. Respiratory sinus arrhythmia responses to cognitive tasks: Effects of task factors and RSA indices. Biol Psychol. 2014; 99:1-14.

9. Tonhajzerova I, Mestanik M, Mestanikova A, Jurko A. Respiratory sinus arrhythmia as a non-invasive index of 'brain-heart' interaction in stress. Indian J Med Res. 2016; 144(11):815-822.

10. Puri SS, Kaundinya SD. Cardiovascular changes due to examination stress in First Year MBBS students. Indian J Basic Appl Med Res. 2016; 5(3):810-816.

11. Kumari N, Kumar A, Kumar M. Comparison of cardiovascular, cognitive and stress parameters in presence and in absence of examination among medical students: An observational and prospective study. Indian J Clin Anat Physiol. 2019; 6(4):462 467.

12. Oyeyemi AY, Atama TI, Lawan A, Oyeyemi AL. Cardiovascular Parameters of Nigerian Physiotherapy Students During an End of Semester Examination. Journal of Medical and Biomedical Sciences. 2015; 4(2):14.

13. Sembulingam $P$, Sembulingam $K$, llango $S$, Sridevi $G$. Rate Pressure Product as a Determinant of Physical Fitness in Normal Young Adults. IOSR-JDMS. 2015; 14(4):8-12.

14. De Meersman RE, Zion AS, Giardina EGV, Weir JP, Lieberman JS, Downey JA. Estrogen replacement, vascular distensibility, and blood pressures in postmenopausal women. Am J of Physiol. 1998; 274(5):1539-1544.

15. Mahajan AS. Stress in Medical Education : a global issue or Much Ado About Nothing specific ? SEAJME. 2010; 4(2):9-13.

16. Abdulghani HM, AlKanhal AA, Mahmoud ES, Ponnamperuma GG, Alfaris EA. Stress and its effects on medical students: A cross-sectional study at a college of medicine in Saudi Arabia. J Health Popul Nutr. 2011; 29(5):516-522.

17. Dogan S, Nalcaci N, Dogan S, Badnjevic A, Kurtovic A, Marjanovic D. Changes in Blood Pressure and Heart Rate Measurement Undergraduate Students During Exam Period. J Biom Biostat. 2017; 8(2):1-5.

18. Al-sandook TA, Al-nuaimy KMT, Al-saffar MT. Effect of stress on arterial blood pressure In dental students. Al-Rafidain Dental Journal. 2007; 7(2):118-121.

19. DeMers D, Wachs D. Physiology, Mean Arterial Pressure [ebook]. StatPearls Publishing; 2019.

20. Ritz,Thomas, Wilhelm FH, Meuret AE, Gerlach AL, Roth WT. Airway response to emotion- and disease-specific films in asthma, blood phobia, and health. Psychophysiology. 2011; 48(1):121-135

21. Jongste JCDE, Jongejan RC, Kerrebijn KF. Control of Airway Caliber by Autonomic Nerves in Asthma and in Chronic Obstructive Pulmonary Disease. Am Rev Respir Dis. 1991; 143(6):14211426.
22. Ritz T, Steptoe A, DeWilde S, Costa M. Emotions and stress increase respiratory resistance in asthma. Psychosom Med. 2000; 62(3):401-412.

23. Kang DH, Fox $\mathrm{C}$. Neuroendocrine and leukocyte responses and pulmonary function to acute stressors. Ann Behav Med. 2000; 22(4):276-285.

24. Tipton MJ, Harper A, Paton JFR, Costello JT. The human ventilatory response to stress: rate or depth? J Physiol. 2017; 595(17):5729-5752.

25. Acharya A, Sharma M. Acute effect of examination stress on cardiovascular parameters. Int J Med Health Res. 2017; 3(10):13.

26. Fejes I, Ábrahám G, Légrády P. The effect of an exam period as a stress situation on baroreflex sensitivity among healthy university students. Blood Press. 2020; 29(3):175-181.

27. Quintana DS, Heathers JAJ. Considerations in the assessment of heart rate variability in biobehavioral research. Front Psychol. 2014; 5:805.

28. Fortunato CK, Gatzke-Kopp LM, Ram N. Associations between respiratory sinus arrhythmia reactivity and internalizing and externalizing symptoms are emotion specific. Cogn Affect Behav Neurosci. 2013; 13(2):238-251. 